\title{
Understanding and Dealing the SARS-CoV-2 Infection: An Updated Concise Review
}

\author{
Md. Jamal Hossain ${ }^{1}$, Md. Ruhul Kuddus' ${ }^{1}$, Mohammad A. Rashid ${ }^{1}$ \\ and Md. Zakir Sultan ${ }^{2}$ \\ ${ }^{1}$ Department of Pharmaceutical Chemistry, Faculty of Pharmacy, University of Dhaka \\ Dhaka-1000, Bangladesh \\ ${ }^{2}$ Centre for Advanced Research in Sciences (CARS), University of Dhaka \\ Dhaka-1000, Bangladesh
}

(Received: August 12, 2020; Accepted: December 19, 2020; Published (web): January 28, 2021)

\begin{abstract}
Viral infection has made the world to pass through the most critical time of the current century. In December 2019, the Wuhan city of China faced a novel etiological viral agent with atypical secondary pneumonia. The unique virus was severe acute respiratory syndrome coronavirus-2 (SARS-CoV-2) that caused coronavirus disease 2019 (COVID-19) pandemic. According to the worldometer data, as of December 24, 2020, the world lost more than 1.74 million lives and infected more than 79.3 million people with the novel coronavirus-2. As there is no approved drug to combat the disease or vaccine against the virus, the infection continuously triumphed over the current medical system. The epidemiological analysis showed that geriatric patients are generally the most susceptible to the viral infection, and pediatric patients exhibited milder complications. The clinical characteristics of COVID19 displayed that the most frequent symptoms are dry cough, fever, dyspnea, and sputum production. Herd immunity is a tested strategy that could moderate viral transmission in developing countries. In this study, authors abridged the epidemiological outcomes, clinical features, and pathophysiology of SARSCoV-2 infection. The article also focused on vaccine development, herd immunity, and the most promising repurposed therapeutics for the treatment of COVID-19 with their clinical trial updates.
\end{abstract}

Key words: COVID-19, SARS-CoV-2, clinical characteristics, pathophysiology, herd immunity, repurposed therapeutics, clinical trials

\section{Introduction}

The first fatal case of coronavirus disease 2019 (COVID-19) was surfaced from Wuhan, Hubei province, China, during late December of 2019 as severe infectious respiratory disorders leading to death (Zhang and Holmes, 2020; Yu et al., 2020). Soon after that, a novel Severe Acute Respiratory Syndrome Coronavirus 2 (SARS-CoV-2) was found responsible for this. The source of this unique virus was primarily envisaged through a zoonotic transmission from a seafood market of Wuhan and recognized to have a stronger capacity to cause a human to human transmission (Andersen et al., 2020; Zhang and Holmes, 2020), even though many claims for artificially creating this virus in the laboratory was also noticed (Latham, 2020). The International Committee of Taxonomy of Viruses named this virus as SARS-CoV-2 due to its $\sim 80 \%$ genetic homology to SARS-CoV (also known as SARS-CoV-1), causing an infection outbreak in 2002-2003 starting from China to many other places of the world (Yuki et al., 2020). The World Health Organization (WHO) has assessed the alarming condition of severity and spreading of COVID-19 and declared this novel

Corresponding author: Md. Zakir Sultan; E-mail: zakir.sultan@du.ac.bd

DOI: https://doi.org/10.3329/bpj.v24i1.51637 
outbreak as a pandemic on March 11, 2020 (Hossain et al., 2020).

Numerous scientific articles addressed this virus as the seventh member of the $\beta$ coronavirus genus and coronavirdiae family (Wrapp et al., 2020). The largest known single-stranded, positive sense spherical enveloped RNA virus has already extended its pervasiveness to more than two hundred and fifteen countries throughout the six continents of the world (Ceraolo and Giorgi, 2020; Li and Clercq, 2020; Wang et al., 2016). The SARS-CoV-2 virus mainly attacks the respiratory tract and causes primary symptoms like fever, dry cough, sore throat, dyspnea, headache, dizziness, nausea, and vomiting (Huang et al., 2020). A large percentage of COVID19 infected patients in China exhibited septic shock, coagulation dysfunctions, and metabolic-acidosis in the critical phase. It is well established that the symptoms of COVID-19 disease are now highly heterogeneous, from simple clinical symptoms to hypoxia with acute respiratory distress syndrome (ARDS) for critically ill patients (Huang et al., 2020; Guan et al., 2020). Recent epidemiological studies have reported that the SARS-CoV-2 mortality rate is the highest for geriatric patients and the lowest for pediatric patients (Zhou et al. 2020; Qiu et al. 2020).

As there is no approved drug or vaccine against the SARS-CoV-2 infection, the clinical managements are the ubiquitous weapons to recover the infection. Here, the article was intended to review the current updates of epidemiology, clinical features, pathophysiology, and promising treatments of COVID-19.

\section{Epidemiology}

Sources, spectrum, and routes of the infection: Currently, the primary source of the virus is SARSCoV-2 infected patients. The people who are not showing significant signs and symptoms, i.e., the asymptomatic patients, might be considered potential sources of this viral infection. Critically ill patients are envisaged as more contagious than mild or moderate patients (Jin et al., 2020). It has been reported that most of the COVID-19 cases recovered within 1-2 weeks, where $1.2 \%$ were asymptomatic patients (Lu et al., 2020a).

The main transmission routes of the virus have been identified as the respiratory droplets and physical contact of the infected patients (Jin et al., 2020). Morawska and Milton (2020) have recently reported the significant airborne transmission of the virus. They suggested taking preventive measures to prevent this potential route of transmission. However, it was not confirmed that the people would be infected or not after consumption of contaminated food products, and no clear evidence has been proved that the virus may transmit from mother to child during pregnancy or childbirth (Jin et al., 2020).

Basic reproduction number and incubation period: The basic reproduction or reproductive number $\left(\mathrm{R}_{0}\right)$ of infection means the average number of infected patients from one patient in a population over the infectious period. Zhao et al. (2020) estimated the $\mathrm{R}_{0}$ value in mainland China 2.24 (95\% confidence interval, $\mathrm{CI}=1.96-2.55)$ to $3.58(95 \% \mathrm{CI}$ $=2.89-4.39$ ) by a data-driven analysis during the early phase of the outbreak. Tang et al. (2020a) indicated the $R_{0}$ value by deterministic compartmental model analysis for COVID-19 during late January 2020, and it was 6.47 (95\% CI $=5.71$ 7.23). The WHO measured the $\mathrm{R}_{0}$ value as 1.4-2.5 (Tang et al., 2020b). The $\mathrm{R}_{0}$ value was less than one for infection of Middle East Respiratory Syndrome coronavirus (MERS-CoV), and it was reported to be 2-5 for SARS-CoV infection (Zhao et al., 2020).

The incubation period assists in making case definitions and measure the quarantine durations during the pandemic. The model-based basic reproductive number is the most vital epidemiological factor, which is a prerequisite to determine the viral transmissibility. A dynamics study on confirmed 425 COVID-19 patients (median age 59 and male 56\%) regarding the early transmission in Wuhan, China, reported that the average incubation period was five days $(95 \% \mathrm{CI}=$ 4.1-7.0). The same study also estimated the basic reproductive number, and it was $2.2(95 \% \mathrm{CI}=1.4$ - 
3.9) (Li et al., 2020a). Another study with 88 COVID-19 positive patients found the average incubation period 6.4 days $(95 \% \mathrm{CI}=5.6-7.7)$, and it was ranged from 2.1 to 11.1 days (2.5th to 97.5 th percentile) (Backer et al., 2020).

Worldwide current COVID-19 cases: As of December 24, 2020, the worldometer counted near 79.4 million SARS-CoV-2 infected patients, and around 1.75 million patients lost their precious lives. The good news is that more than 55.8 million patients got the medical declerations as COVID-19 negative.
Table 1 represented the total SARS-CoV-2 infected patients of the most 30 countries of the world and their percentage of contribution of global cases up to December 24, 2020. The United Staes of America (USA) contributed the highest percentage of infections $(\mathrm{n}=18,923,693 ; 23.89 \%)$ followed by India $(\mathrm{n}=10,130,066 ; 12.79 \%)$, Brazil $(\mathrm{n}=7,366,677$; 9.37\%), and Russia $(n=2,963,688 ; 3.74 \%)$. In the perspective of COVID-19 infections, Bangladesh $(\mathrm{n}=506,102 ; 0.64 \%)$ was staying at $27^{\text {th }}$ position of the worldwide cumulative cases (Table 1).

Table 1. Countrywise cases distribution up to December 24, 2020. (Data source: https://www. worldometers.info/coronavirus/worldwide-graphs/).

\begin{tabular}{|c|c|c|c|c|}
\hline Serial no. & Country & First reporting date & Total cases & $\%$ of global cases \\
\hline 1 & USA & January 20, 2020 & $18,923,693$ & 23.89 \\
\hline 2 & India & January 30, 2020 & $10,130,066$ & 12.79 \\
\hline 3 & Brazil & February 25, 2020 & $7,366,677$ & 9.37 \\
\hline 4 & Russia & January 31, 2020 & $2,963,688$ & 3.74 \\
\hline 5 & France & January 24, 2020 & $2,505,875$ & 3.16 \\
\hline 6 & UK & January 31, 2020 & $2,114,551$ & 2.71 \\
\hline 7 & Turkey & March 11, 2020 & $2,082,610$ & 2.63 \\
\hline 8 & Italy & January 31, 2020 & $1,991,278$ & 2.51 \\
\hline 9 & Spain & January 31, 2020 & $1,847,874$ & 2.33 \\
\hline 10 & Germany & January 27, 2020 & $1,599,177$ & 2.02 \\
\hline 11 & Argentina & March 3, 2020 & $1,563,865$ & 1.97 \\
\hline 12 & Colombia & March 6, 2020 & $1,544,826$ & 1.95 \\
\hline 13 & Mexico & February 29, 2020 & $1,350,079$ & 1.70 \\
\hline 14 & Poland & March 4, 2020 & $1,239,998$ & 1.57 \\
\hline 15 & Iran & February 19, 2020 & $1,183,182$ & 1.49 \\
\hline 16 & Peru & March 6, 2020 & $1,002,263$ & 1.27 \\
\hline 17 & Ukraine & March 3, 2020 & $1,001,132$ & 1.26 \\
\hline 18 & South Africa & March 5, 2020 & 954,258 & 1.20 \\
\hline 19 & Netherlands & February 27, 2020 & 721,071 & 0.91 \\
\hline 20 & Indonesia & March 2, 2020 & 692,838 & 0.87 \\
\hline 21 & Czech Republic & March 1, 2020 & 660,461 & 0.83 \\
\hline 22 & Belgium & February 4, 2020 & 632,321 & 0.80 \\
\hline 23 & Romania & February 26, 2020 & 608,561 & 0.77 \\
\hline 24 & Chile & March 3, 2020 & 590,914 & 0.75 \\
\hline 25 & Iraq & February 22, 2020 & 588,803 & 0.74 \\
\hline 26 & Canada & January 27, 2020 & 528,354 & 0.67 \\
\hline 27 & Bangladesh & March 8, 2020 & 506,102 & 0.64 \\
\hline 28 & Philippines & January 30, 2020 & 465,724 & 0.59 \\
\hline 29 & Pakistan & February 26, 2020 & 465,070 & 0.59 \\
\hline 30 & Switzerland & February 25, 2020 & 428,197 & 0.54 \\
\hline
\end{tabular}


COVID-19 and Bangladesh perspectives: The current novel epidemic in Bangladesh is a part of the COVID-19 global pandemic. Dhaka, the capital city of Bangladesh, has faced its first three SARS-CoV-2 infected patients on March 8, 2020, whereas two of them were returnees from Italy (Hossain, 2020a). To protect the country's people from this new threat, the Government of Bangladesh has declared 'lockdown' in the whole region and taken precautionary measures to spread awareness among the population of the country (Mamun, 2020). Although the infection rate was negligible until March, it grew up at an exponential rate from early May. On May 6, all districts of the country have experienced COVID-19 infected patients. Among them, Rangamati was the last one. The recovery number of patients from SARS-CoV-2 infection has exceeded the number of active cases on July 12 (https://corona.gov.bd/). According to worldometer data, as of December 24, 2020, Bangladesh counted its total cases of infection of 506, 102 with 7,378 deaths, and till the same date, 446,690 patients got recovered from COVID-19 infection.

\section{Clinical characteristics}

The most frequent symptoms of COVID-19 infected patients are fever, dry cough, sore throat, chest tightness, dyspnea, sputum production, fatigue, and diarrhea. More than $80 \%$ of cases were reported as mild to moderate illness (Lake, 2020). The clinical features of 2,985 patients with COVID-19 from six distinct sources (Guan et al., 2020; Wang et al., 2020a; Xiong et al., 2020; Chen et al., 2020; Wang et al., 2020b; Huang et al., 2020) were observed. The number of patients from the six references were 1099, 1012, 421, 274, 138, and 41, respectively (Guan et al., 2020; Wang et al., 2020a; Xiong et al., 2020; Chen et al., 2020; Wang et al., 2020b; Huang et al., 2020). All the patients were adult-aged, and the mean age of the patients was 50.53 years. The males and females were $1,639(54.90 \%)$ and 1,343 (44.99\%), respectively, $21.31 \%$ were 65 years or more. Among the total patients, 1,914 (64.12\%) patients suffered from fever, and almost $61 \%$ of patients faced coughing. From the four studies (Guan et al., 2020; Chen et al., 2020; Wang et al., 2020b; Huang et al., 2020), it was reported that 1,552 patients showed fatigue. The other prevalent symptoms were sputum production $(\mathrm{n}=753 ; 25.22 \%)$, shortness of breath $(\mathrm{n}=662 ; 22.17 \%)$, myalgia or arthralgia $(\mathrm{n}=556 ; 18.62 \%)$, chills $(\mathrm{n}=405$ out of $2,532 ; 15.99 \%)$, sore throat $(n=423$ out of 2,670 ; $15.84 \%)$, and headache $(n=389 ; 13.3 \%)$. Diarrhea was noted as the least $(n=292 ; 9.95 \%)$. The observed coexisting complications were chronic obstructive pulmonary disease (COPD), hypertension, diabetes, coronary heart disease (CHD), cerebrovascular disease, chronic kidney disease (CKD), hepatitis, tuberculosis, human immunodeficiency virus (HIV), chronic liver disease, cancer, malignancy, and other disorders.

Hematological profile: Most patients showed the normal range of neutrophil count $(1.8-6.3) \times 10^{9} / \mathrm{L}$. Notably, the ICU patients showed higher neutrophil count than the non-ICU patients [median (IQR): 4.6 (2.6-7.9) vs. 2.7 (1.9-3.9); $p<0.001]$ (Wang et al., 2020b). In white blood cell (WBC) count from the four studies (Guan et al., 2020; Wang et al., 2020b; Chen et al., 2020; Huang et al., 2020), 28.59\% $(\mathrm{n}=537$ out of 1,878$)$ patients showed the decreased level than the normal range $(3.5-9.5) \times 10^{9} / \mathrm{L}$, and $7.34 \%(n=137$ out of 1,878$)$ exhibited the elevated level. The ICU patients exhibited higher WBC count than the non-ICU patients [6.6 (3.6-9.8) vs. 4.3 (3.3$5.4) ; p=0.003]$. The lymphocyte count was found $0.8(0.6-1.1)$ [ICU vs. non-ICU $=0.8(0.5-0.9)$ vs. 0.9 (0.6-1.2); $p=0.03$ ] which is lower than the normal range $(1.1-3.2) \times 10^{9} / \mathrm{L}$. The median monocyte and platelet counts were observed in the normal range (Wang et al., 2020b).

\section{Pathophysiology}

Cell entry and infection stages: The SARS-CoV2 virus enters the body via respiratory droplets or contact from the infected patients, and potentially oral route. Initially, the virus is presumed to use in 
the nasal cavity, pharynx, i.e., the upper respiratory tract. Then it utilizes the lower respiratory tract and gastrointestinal mucosa to proliferate the viral counts (Xiao et al., 2020). Very few SARS-CoV-2 infections are dominated at that point, and it was reported as asymptomatic (Figure 1). The asymptomatic stage may be as long as 1 or 2 days after the viral infection, where some local replication might be happened (Mason, 2020). In some cases, it was reported as a non-respiratory illness like acute kidney, liver, and cardiovascular disorders (Jin et al., 2020). Angiotensin-converting enzyme 2 (ACE 2) has been proven as a principal receptor for binding the cell surface to enter into the cell (Hoffmann et al., 2020). After the cell entry, the virus propagates more, conducts the airway regulation, and triggers the innate immune responses. This is the second stage, and approximately $80 \%$ of patients recover from this mild stage via symptomatic therapy (Mason, 2020). Unfortunately, around $20 \%$ of the most vulnerable patients develop the third stage of severe SARS$\mathrm{CoV}-2$ infection. Initially, the mortality rate is about $2 \%$, which is varying reportedly with the age groups (Wu and McGoogan, 2020). In the third stage, the virus infects the units of the lung, the type II alveolar cells which are responsible for exchanging the gas. Scientists suggested monitoring this progression of the third stage of SARS-CoV-2 infection, which might be required to serve as the best facility to recover (Mason, 2020).

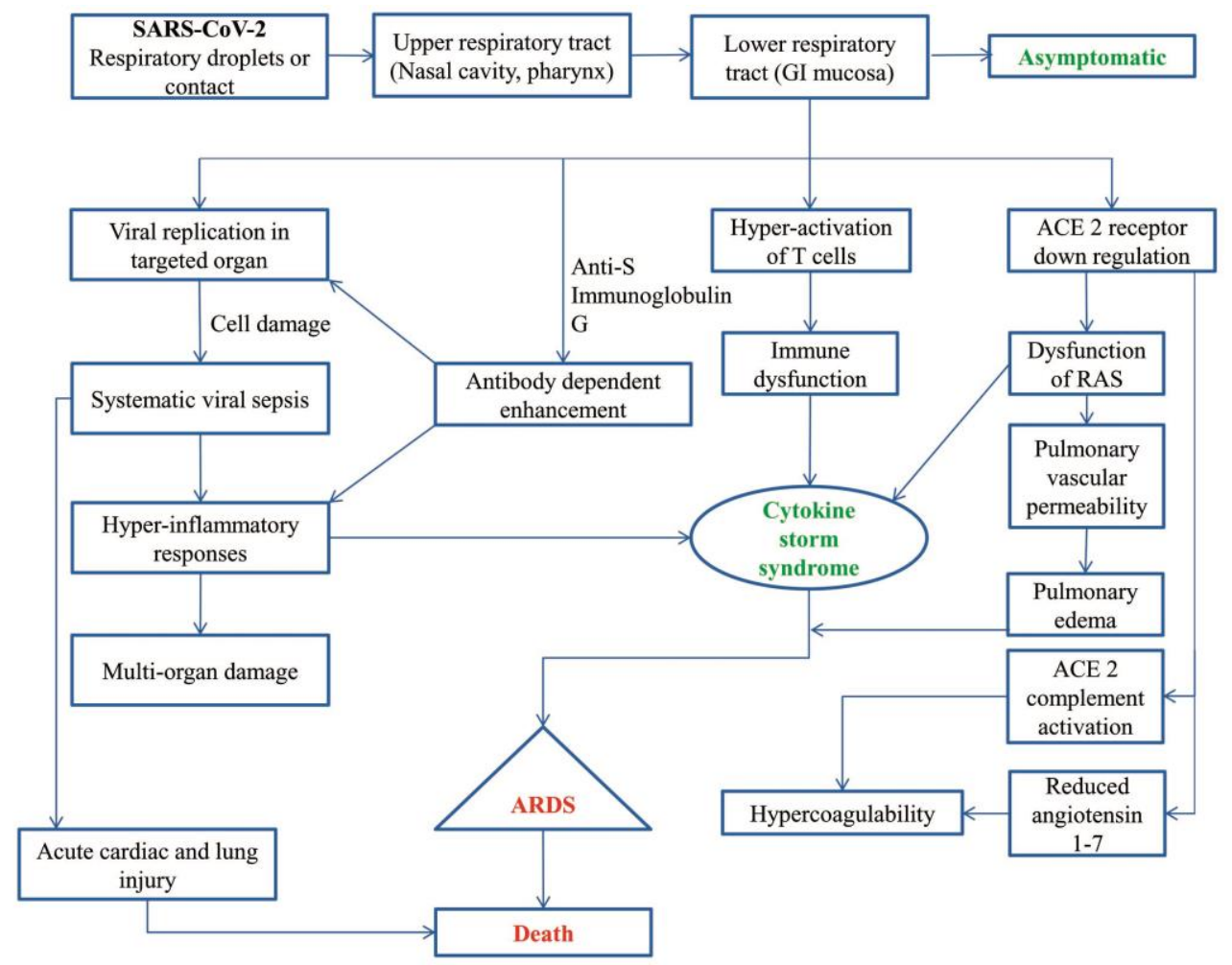

Figure 1. Plausible pathogenesis of SARS-CoV-2 infection in the human body. SARS-CoV-2: severe acute respiratory syndrome coronavirus 2; GI mucosa: Gastrointestinal mucosa; ACE 2: angiotensin-converting enzyme 2; RAS: reninangiotensin system; ARDS: acute respiratory distress syndrome. The figure was examined and supported by previous published literatures (Jin et al., 2020; Mason, 2020).

Genetical and biochemical features: The novel SARS-CoV-2 virus has shown a similar characterization and genomic sequencing at around $80 \%$ with SARS and 50\% with MERS bat-derived coronavirus. In contrast, the phylogenetic analysis suggested the dissimilarity of SARS-CoV-2 with the previous both coronavirus (MERS-CoV and SARS$\mathrm{CoV})$, as it has belonged to the $\beta$-coronavirus genus 
(Lu et al., 2020b). It was reported that there are four significant glycoproteins in the surface of the SARSCoV-2 virus [(Spike (S), membrane (M), envelop $(\mathrm{E})$, and nucleocapsid $(\mathrm{N})$ ]. Amongst them, the spike protein significantly binds with the ACE 2 receptor located on the surface of the host cell, which is highly expressed in the lung, heart, kidney, and bladder (Zou et al., 2020). The spike protein consists of two subunits ( $\mathrm{S} 1$ and $\mathrm{S} 2$ ), which are responsible for binding to the ACE 2 receptor binding and for the cell fusion, respectively (Kuhn et al., 2004). Moreover, the $\mathrm{S}$ protein forms a crown-like appearance of the virus by extending itself from the membrane. Homology modeling analysis showed that the SARS-CoV also used to enter the host cell via the same receptor, while MERS-CoV utilized the dipeptidyl-peptidase-4 (DPP-4) receptor (Wan et al., 2020; Li et al., 2020b). However, this novel virus transmits with a 3 and 10 fold higher transmission rate than the SARS and MERS-CoV viruses, respectively (Jiang and Shi, 2020).

Mechanism of SARS-CoV-2 invasion: In brief, the life cycle of the SARS-CoV-2 virus in the host cell consists of five processes: attachment, penetration, biosynthesis, maturation, and release
(Figure 2). Firstly, the virus binds to the host cell receptor ACE 2 (attachment process) and enters into the cell via the endocytosis process (penetration). Then the viral cell is supposed to be released in the cytoplasm and thrusts into the nucleus for its replication. The viral proteins are biosynthesized by utilizing viral mRNA. Then the new viral particles are matured and released (Yuki et al., 2020). Among all proteins of the virus, the envelope protein plays a major role during the maturation and budding, as it localizes in the Golgi or endoplasmic reticulum (ER). After the S1 subunit of the spike protein of the virus binds with the ACE 2 receptor, the conformation change of the protein provokes the envelope fusion via the endosomal process in the cell membrane. Then the virus releases its genetic material into the cell. By the effect of viral proteinases, the RNA cleaves into some small products. A series of subgenomic mRNA materials which are finally translated to the viral proteins through transcription and translation processes. Then the viral proteins are assembled into the ER/Golgi apparatus, which are transported through vesicles. Finally, the viral genomic materials and proteins are released out of the cell (Sherren et al., 2020).

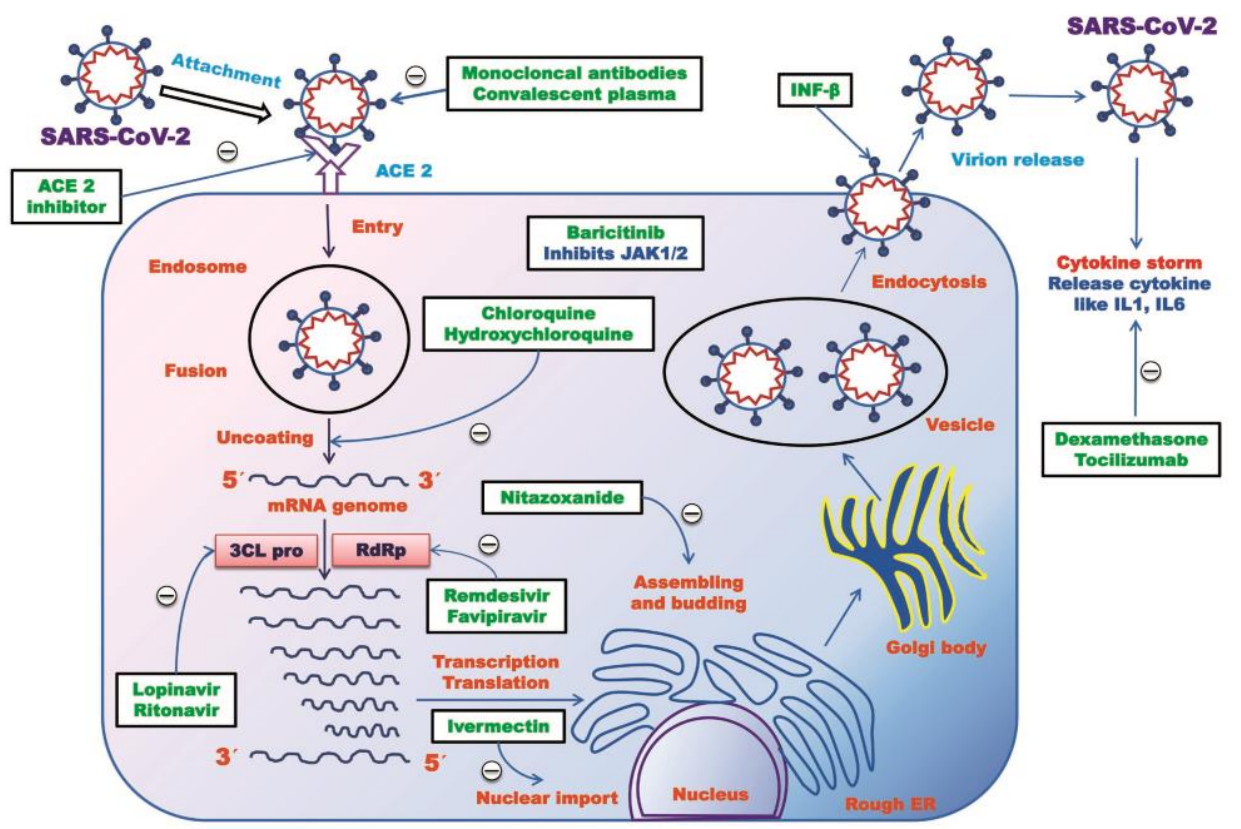

Figure 2. The life cycle of SARS-CoV-2 in the host cell and the proposed drug targets against the virus. The figure was verified and supported by previous published literatures (Pandey et al., 2020; Hossain and Rahman, 2020). 


\section{Concurrent treatments of COVID-19}

Promising repurposed therapeutic options: Due to the novelty of COVID-19, the world community still lacks any approved vaccine or effective therapeutic option against the virus. The primary treatment of SARS-CoV-2 infection is palliative care. Currently, outpatient management to intensive care is based on supportive and symptomatic treatments to save lives. As the SARS-CoV-2 virus is an RNA virus, it was also reported that the virus is $80 \%$ similar to genetically with SARS-CoV; the drugs used to fight the SARS-CoV, MERS-CoV successfully or potentially, can be repurposed to combat this novel virus. The new drug development process is also long. Therefore, drug repurposing is the best strategy to fight pandemics instantly. Since the outbreak, some antivirals, anti-parasitic, and immune-modulating drugs are being prescribed urgently to the COVID-19 positive patients (Hossain and Rahman, 2020).

Antiviral therapy: Numerous antiviral drugs like remdesivir, favipiravir, lopinavir/ritonavir,interferonbeta, darunavir, oseltamivir, etc., were reported as promising drugs against COVID-19. Remdesivir is an approved drug to treat the Ebola virus (Al-Tawfiq et al., 2020), and favipiravir is used against the influenza virus (Shiraki and Daikoku, 2020). As both drugs are the blockers of RNA-dependent RNA polymerase (RdRp) enzyme (Figure 1), these antivirals drugs showed in vitro anti-COVID-19 property (Sheahan et al., 2017; Shiraki and Daikoku, 2020). Both antiviral drugs are nucleoside analogbased drugs, which act on the RdRp enzyme and inhibit the replication of RNA viruses, like coronavirus ( $\mathrm{Li}$ and Clercq, 2020). Recently, a preliminary report of a double-blind, placebocontrolled, randomized trial (NCT04280705) has been published by analyzing data obtained from 1,059 COVID-19 patients (remdesivir=538 and placebo=521) (Beigel et al., 2020). The drug has been observed to minimize the median recovery time from 15 to 11 days and decreased the mortality rate from $11.9 \%$ to $7.1 \%$. In the meantime, the United States Food and Drugs Administration (USFDA) published an authorization letter for the emergency use of remdesivir (USFDA, 2020).

The health ministry of Russia issued a temporary approval of favipiravir (Avifavir) to use in the treatment of COVID-19 after getting a positive outcome of a clinical trial on 330 patients. The drug showed a safety profile with no significant adverse effects (Trial Site News, 2020). Another doubleblind, placebo-controlled, randomized trial was conducted in Bangladesh (Dhaka Trial) on 50 patients with COVID-19. The study found $44 \%$ more viral clearance than placebo (RT-PCR negative: favipiravir vs. placebo $=96 \%$ vs. $52 \%$ after 10 days) (Hossain and Rahman, 2020).

Another potential anti-COVID-19 therapy is the combination of lopinavir/ritonavir (Pandey et al., 2020). Lopinavir is used in conjunction with ritonavir to treat the human immune deficiency virus (HIV). Lopinavir acts as an HIV-1 protease enzyme inhibitor, where ritonavir blocks the CYP3A4 metabolizing enzyme and enhances the plasma level of lopinavir (Kaplan and Hicks, 2005; Podzamczer et al., 2015). A trial (ChiCTR2000029308) on 199 hospitalized COVID-19 patients showed no significant benefit of lopinavir/ritonavir compared to standard care only (Cao et al., 2020). Another openlabel, randomized phase II clinical trial (NCT04276688) for triple combination therapy of LPV/RTV (400 mg/100 mg twice daily), ribavirin (400 mg twice daily), and INF beta- $1 \mathrm{~b}$ ( 3 doses of 8 million IU on alternate days) was conducted by Hung et al. (2020) on 127 COVID-19 patients. The study established the triple therapy safety profile and found superior activity than the lopinavir/ritonavir alone to reduce complications and shorten the viral clearance time. However, WHO Solidarity Trial Consortium (2020) has recently reported its interim results that the repurposed drugs like remdesivir, hydroxychloroquine, lopinavir, and interferon beta-1a exhibited little or no effect on COVID-19 hospitalized patients in the duration of hospital stay, initiation of ventilation, and overall mortality. 
Anti-parasitic therapy: Chloroquine or hydroxychloroquine, is an approved antimalarial and autoimmune disease drug. During the early phase of the COVID-19 pandemic, hydroxychloroquine was reported as promising anti-SARS-CoV-2 therapy in numerous scientific articles. It has a weak basic property that increases the endosomal $\mathrm{pH}$. The high $\mathrm{pH}$ prevents cell fusion and enzyme activation, which is essential for viral replication (Salata et al., 2017). The drug also blocks viral entry by halting the glycosylation of ACE 2 on the surface of the host cell (Vincent et al., 2005). The use of hydroxychloroquine with azithromycin had been excellent breaking news after the publication of a nonrandomized, open-label clinical trial in March of the year 2020 (Gautret et al., 2020). Unfortunately, hydroxychloroquine has failed to be established as an anti-COVID-19 drug finally, due to its high side effects concluded by a big open-label, randomized, controlled, and multicenter clinical trial (Tang et al., 2020c).

Another proposed anti-COVID-19 drug, ivermectin, is an FDA-approved broad-spectrum antiparasitic drug to treat river blindness (Pandey et al., 2020). Many studies found ivermectin's activity against RNA viruses like HIV, flavivirus, influenza, dengue, West Nile virus, and a few cancer cells (Hossain and Rahman, 2020). It was recently reported that ivermectin showed the in vitro antiCOVID-19 activity (Caly et al., 2020). A pilot study of phase I trial on 87 COVID-19 patients in Iraq showed more efficacious of ivermectin group $(100 \%$ cure), smaller hospital stay $(7.62 \pm 2.7$ vs. $13.22 \pm$ 0.90 days), and comparatively safer than its control group (hydroxychloroquine + azithromycin) (Hossain and Rahman, 2020). Another recently published double-blind, placebo-controlled, randomized trial conducted in Dhaka, Bangladesh, on 72 COVID-19 patients reported that a 5-day course of ivermectin was found to be safer and effective against mild COVID-19 adult patients (Viral clearance: ivermectin group vs. placebo group $=9.7$ days vs. 12.7 days; $p=$ 0.02) (Ahmed et al., 2020). However, some larger clinical trials (for example, NCT04381884, NCT04429711, NCT04391127, NCT04360356) have been started to ensure its safety and efficacy against COVID-19.

Nitazoxanide is a broad-spectrum antiviral drug that has been repurposed for the treatment of some RNA viruses which was originally developed and commercialized as an antiprotozoal agent (Rossignol, 2014). Initially, nitazoxanide was developed as an antiprotozoal drug. This safe drug showed high potency against broad-spectrum DNA and RNA virus in cell culture assays (Rossignol, 2014). In LLCMK2 cell culture, the $\mathrm{EC}_{50}$ value for NTZ was found $0.92 \mu \mathrm{M}$ which indicated the potency of NTZ against COVID-19 (Rossignol, 2020). Some clinical trials (for example: NCT04360356) are ongoing to establish its final safety and efficacy against the SARS-CoV-2 infection (Table 2).

Immune-modulating therapy: Baricitinib is a Janus kinase (JAK) inhibitor, which is currently prescribed to treat mild to severe rheumatoid arthritis (Favalli et al., 2020). It also blocks the viral entry to the cell by blocking adapter protein-2 associated kinase protein 1 (AAK1). A group of scientists recently proposed that baricitinib might be a potential anti-SARS-CoV-2 drug as regular dosing (Richardson et al., 2020). Kalil et al. (2020) conducted a randomized, double-blind, placebocontrolled clinical trial on 1033 adult patients with COVID-19. They reported that baricitinib plus remdesivir was better than remdesivir alone to shorten recovery time and improve clinical status. However, some clinical studies (for example: NCT04320277, NCT04321993) have been started to establish the safety and efficacy of the drug against COVID-19.

Tocilizumab, another potential drug in the treatment of COVID-19, is an interleukin-6 (IL-6) receptor blocker. This recombinant monoclonal antibody is frequently prescribed in rheumatoid arthritis (Abdallah et al., 2017). Since COVID-19 is recognized with hyper-inflammation, with extreme production of interleukin that causes cytokine storm syndrome (Mehta et al., 2020). In this regard, tocilizumab or JAK inhibitor may prevent the cytokine storm (Xu et al., 2020). A large 
observational cohort study on 1,351 hospitalized SARS-CoV-2 infected patients with severe pneumonia has demonstrated that tocilizumab decreased the fatality rate of critically ill patients and need for the mechanical ventilation (adjusted hazard ratio, $0.61 ; 95 \%$ confidence interval [CI], 0.40-0.92; $p=0.020)$ (Guaraldi et al., 2020). These preliminary promising outcomes motivated for large randomized clinical trials. However, a recently published randomized, double-blind, placebo-controlled trial on 243 SARS-CoV-2 infected patients showed that the drug was not effective to avert intubation or death in moderately ill hospitalized patients (Stone et al., 2020).

Table 2. Ongoing clinical trials of the most promising therapeutics for COVID-19 (data source: https://clinicaltrials. gov/ct2/home)

\begin{tabular}{|c|c|c|c|c|c|c|}
\hline $\begin{array}{l}\mathrm{Sr} \\
\text { no. }\end{array}$ & Drug & Drug type & ROA & Phase & $\begin{array}{l}\text { ClinicalTrials.gov } \\
\text { identifier }\end{array}$ & Duration of study \\
\hline \multirow[t]{2}{*}{1} & \multirow[t]{2}{*}{ Remdesivir } & \multirow[t]{2}{*}{ Antiviral } & \multirow[t]{2}{*}{ IV infusion } & \multirow[t]{2}{*}{ III } & NCT04431453 & Jul, 2020 to Jan, 2021 \\
\hline & & & & & NCT04330690 & Mar, 2020 to May, 2022 \\
\hline 2 & Favipiravir & Antiviral & Oral & III & NCT04336904 & Mar, 2020 to Jul, 2020 \\
\hline 3 & Lopinavir/ritonavir & Antiviral & Oral & II & NCT04330690 & Mar, 2020 to Mar, 2022 \\
\hline 4 & Ivermectin and nitazoxanide & $\begin{array}{l}\text { Antiparasitic, } \\
\text { Antiviral }\end{array}$ & Oral & II, III & NCT04360356 & May, 2020 to Dec, 2020 \\
\hline 5 & $\begin{array}{l}\text { Hydroxychloroquine, } \\
\text { Oseltamivir, Azithromycin }\end{array}$ & $\begin{array}{l}\text { Antiparasitic, } \\
\text { Antiviral, } \\
\text { Antibiotic }\end{array}$ & Oral & III & NCT04338698 & Apr, 2020 to Nov, 2020 \\
\hline 6 & $\begin{array}{l}\text { i) Lopinavir/ritonavir } \\
\text { ii) Hydroxychloroquine } \\
\text { sulfate, } \\
\text { iii) Baricitinib, } \\
\text { iv) Sarilumab. }\end{array}$ & $\begin{array}{l}\text { Antiviral, } \\
\text { Antiparasitic, } \\
\text { Immune- } \\
\text { modulating }\end{array}$ & $\begin{array}{l}\mathrm{i}, \mathrm{ii}, \& \text { iii } \\
\text { Oral route, } \\
\text { iv. S.C } \\
\text { injection }\end{array}$ & II & NCT04321993 & Apr, 2020 to Mar, 2022 \\
\hline 7 & Baricitinib & $\begin{array}{l}\text { Immune- } \\
\text { modulating }\end{array}$ & IV & II, III & NCT04340232 & Jun, 2020 to Oct, 2020 \\
\hline 8 & $\begin{array}{l}\text { Lopinavir/ritonavir vs } \\
\text { Hydroxychloroquine sulfate }\end{array}$ & $\begin{array}{l}\text { Antiviral, } \\
\text { Antiparasitic }\end{array}$ & Oral & III & NCT04403100 & Jun, 2020 to Nov, 2020 \\
\hline 9 & $\begin{array}{l}\text { i) Remdesivir, } \\
\text { ii) Lopinavir/ritonavir, } \\
\text { iii) interferon } \beta-1 \mathrm{~A} \text {, and iv) } \\
\text { hydroxychloroquine }\end{array}$ & $\begin{array}{l}\text { Antiviral, } \\
\text { Antiparasitic }\end{array}$ & $\begin{array}{l}\text { I.V infusion, } \\
\text { oral route, } \\
\text { SC } \\
\text { injection, } \\
\text { and oral } \\
\text { route, } \\
\text { respectively }\end{array}$ & III & NCT04315948 & Mar, 2020 to Mar, 2023 \\
\hline 10 & Dexamethasone & Corticosteroid & IV & IV & NCT04325061 & Apr, 2020 to Oct, 2020 \\
\hline \multirow[t]{4}{*}{11} & \multirow[t]{4}{*}{ Convalescent plasma } & \multirow{4}{*}{$\begin{array}{l}\text { Immune- } \\
\text { modulating }\end{array}$} & \multirow[t]{4}{*}{ IV } & \multirow[t]{4}{*}{ III } & NCT04372979 & May, 2020 to May, 2021 \\
\hline & & & & & NCT04343755 & Apr, 2020 to Apr, 2021 \\
\hline & & & & & NCT04390178 & Apr, 2020 to Dec, 2020 \\
\hline & & & & & NCT04388410 & Jun, 2020 to Dec, 2020 \\
\hline \multirow[t]{2}{*}{12} & \multirow[t]{2}{*}{ Tocilizumab } & \multirow{2}{*}{$\begin{array}{l}\text { Immune- } \\
\text { modulating }\end{array}$} & \multirow[t]{2}{*}{ IV injection } & \multirow[t]{2}{*}{ II } & NCT04317092 & Mar, 2020 to Dec, 2022 \\
\hline & & & & & NCT04335071 & April, 2020 to Oct, 2020 \\
\hline 13 & $\begin{array}{l}\text { i). Hydroxychloroquine and } \\
\text { ii). Nitazoxanide }\end{array}$ & Antiparasitic & Oral & II, III & NCT04361318 & May, 2020 to Dec, 2020 \\
\hline
\end{tabular}

Note: $\mathrm{ROA}=$ Route of administration; $\mathrm{IV}=$ Intravenous; $\mathrm{SC}=$ subcutaneous.

Dexamethasone (Corticosteroid) is an immunemodulating agent that contributes significantly to immune homeostasis (Stockman et al., 2006). A randomized controlled, open-label, clinical trial on
6,425 COVID-19 patients, conducted by the RECOVERY collaborative group (2020), has been published that dexamethasone reduced the 28-day fatality rate of critically ill patients on ventilator 
support. However, the drug did not show any improvement in moderate or mild patients.

Convalescent plasma therapy is a process of enhancing passive immunity by providing plasma containing neutralizing antibodies. A donor who has recently recovered from SARS-CoV-2 can donate plasma to a COVID-19 patient (Hui and Wong, 2005). As there is no approved vaccine or drug, this low risking therapy can boost the patient's immunity (Arabi et al. 2016). Recently, Simonovich et al. (2020) have published the outcomes of a randomized, double-blind, placebo-controlled, clinical trial of convalescent plasma therapy on 228 patients, where they reported that this therapy exhibited neither decreasing mortality rate nor any clinical improvement. However, currently, some more extensive randomized, double-blind, controlled clinical trials are under investigation to finalize its safety and efficacy for the treatment of COVID-19 (Rajendran et al., 2020).

Vaccination against SARS-CoV-2 infection: The most wanted and long-term effective solution of the current pandemic is to develop a vaccine against the SARS-CoV-2 virus. The undertaken previous attempts to develop a vaccine against the SARS and MERS outbreak introduced sufficient knowledge about the new virus's anatomy and physiology. The established preliminary conceptions expedited the vaccine development against COVID-19 (Diamond and Pierson, 2020). According to WHO, no vaccine is approved for the virus. Till the date, more than 137 vaccine candidates are ongoing under preclinical development, and 23 are in clinical development for COVID-19 prevention (WHO, 2020). Among them, very few vaccines like mRNA (Moderna), ChAdOx1 nCoV-19 (Oxford), Ad5-nCoV (CanSino Biologicals), INO-4800 (Inovio), LV-SMENP-DC, and pathogen-specific aAPC (Shenzhen GenoImmune Medical Institute) are promising which have already entered into clinical trial phases. Another significant breakthrough was created on July 20, 2020, through publishing the preliminary report of phase $1 / 2$, single-blind, randomized, controlled trial of ChAdOx1 nCoV-19 potential vaccine (Folegatti et al., 2020). A total of 1,077 participants (18-55 years) were recruited in the trial, where 543 received the vaccine. In the vaccine group, a dual immune response, i.e., spike-specific T-cell response and antispike IgG response, were observed on days 14 and 28 , respectively, with no serious adverse effects. The ChAdOx1 nCoV-19 vaccine showed well tolerability with an acceptable safety profile. Moreover, the study supported the bigger scale Phase III trial (Folegatti et al., 2020). Recently, UK's medicines and healthcare products regulatory agency (MHRA) has given temporary use approval of the world's first vaccine BNT162b2 (developed by Pfizer and BioNTech) to fight COVID-19 pandemic based on its 95\% protection against SARS-CoV-2 virus in an ongoing placebo-controlled, observer-blinded, multinational trial on 43,548 participants (EPR, 2020; Polack et al., 2020).

Herd immunity and COVID-19: Herd immunity or herd effect or indirect protection is not a novel concept. It indicates the incorporation of a pathogen to a human or animal population to attain immunity against the pathogen. Individuals with no development of self-immunity are defended from the infection indirectly, according to the theory (Rashid et al., 2012). The stated doctrine of herd immunity had been popular in the case of animal husbandry. However, it can protect a large population by restricting the transmission of infectious diseases. The $R_{0}$ value is utilized to determine the threshold percentage $(\mathrm{P})$ of the population required to be immunized for developing herd immunity. The whole community will get rid of the pandemic (Hossain, 2020b).

$$
\mathrm{P}=\frac{\mathrm{R}_{0}-1}{\mathrm{R}_{0}} \times 100 \%
$$

Most of the study showed that the $\mathrm{R}_{0}$ value was lying between 2 to 3 for SARS-CoV-2 infection (Liu et al., 2020). Therefore, the threshold percentage is 50 to $66.67 \%$ population required for achieving indirect protection from the COVID-19 outbreak (Syal, 2020).

During the pandemic time, the hot spots for the infection are the hospitals or clinics, diagnostic 
centers, airports, stations, immigration points, etc. should be covered by the recovered volunteers from COVID-19 as per their expertise setting. The immunized people would be able to limit the spread of the virus and act as a root of indirect protection (Liu et al., 2020). It is important to note here, after the recovery of all symptoms of COVID-19 for 14 days, approximately14\% of patients got RNA test positive in China (An et al., 2020). However, it has been disputable that COVID-19 recovered subjects can be re-infected. It has been considered the reactivation of dormant SARS-CoV-2 infection (Guzman, 2020). Recently, Batisse et al. (2020) published a national case series of 11 re-infected patients with acute COVID-19 and recommended to perform a more extensive study to comprehend the mechanism of these reactivations. Unfortunately, indirect protection will not be effective if the virus would mutate. Nevertheless, herd immunity is an experimented approach. In developing countries, all the places are not homogenously susceptible to the infection. Therefore, localized herd immunity may help in mitigating the spread of COVID-19 (Syal, 2020; Hossain, 2020b).

\section{Conclusions}

Undoubtedly, the COVID-19 outbreak caused by the zoonotic virus has created vigorous troublesome in public health and the international economy. Although the symptoms of SARS-CoV-2 infection are mild to moderate in most of the cases, the infectivity is so high compared to SARS and MERS coronavirus. Until an effective, safe, and approved vaccine is available for everyone, potential repositioned drugs might be suitable candidates to fight COVID-19. Numerous repurposed drugs are undergoing clinical trials, and some of them have already been endorsed in different countries of the world for emergency use or as adjuvant treatment options in COVID-19 in addition to standard of care.

However, the approved vaccines or drugs are far away; therefore, the transmission of COVID-19 must be controlled by concerted efforts. The strict protocols of social distancing, wearing masks, routine washing of hands, and maintaining isolation and quarantine protocols may be the instant solution to prevent its rapid transmission. Particular attention should be given to vulnerable populations, including older adults, children, and health care providers. It is inevitable to monitor the strength and potential routes of human to human transmission of SARS-CoV-2 globally. Anti-COVID-19 drugs or vaccines development must be accelerated, and comprehensive steps should be promoted to prevent any future pandemic.

\section{Conflict of interests}

The authors declared no conflict of interest.

\section{Funding}

The authors did not receive any type of funding for this paper.

\section{References}

Abdallah, H., Hsu, J. C., Lu, P., Fettner, S., Zhang, X., Douglass, W. and Kivitz, A. 2017. Pharmacokinetic and pharmacodynamic analysis of subcutaneous tocilizumab in patients with rheumatoid arthritis from 2 randomized, controlled trials: SUMMACTA and BREVACTA. J. Clin. Pharmacol. 57, 459-468.

Ahmed, S., Karim, M. M., Ross, A. G., Hossain, M. S., Clemens, J. D., Sumiya, M. K. ... and Khan, W. A. 2020. A five day course of ivermectin for the treatment of COVID-19 may reduce the duration of illness. Int. J. Infect. Dis. Published Online: December 2, 2020. DOI: 10.1016/j.ijid.2020.11.191.

Al-Tawfiq, J. A., Al-Homoud, A. H. and Memish, Z. A. 2020. Remdesivir as a possible therapeutic option for the COVID-19. Travel Med. Infect. Dis. 34: 101615. DOI: 10.1016/j.tmaid.2020.101615.

An, J., Liao, X., Xiao, T., Qian, S., Yuan, J., Ye, H. and Zhang, Z. 2020. Clinical characteristics of the recovered COVID-19 patients with re-detectable positive RNA test. Ann. Transl. Med. Published Online: September 2020. DOI: 10.21037/atm-205602.

Andersen, K. G., Rambaut, R., Lipkin, W. I., Holmes E. C. and Garry, R. F. 2020. The proximal origin of SARS-CoV-2. Nat. Med. 26, 450-455.

Arabi, Y. M., Hajeer, A. H., Luke, T., Raviprakash, K., Balkhy, H., Johani, S. and Alahmadi, M. 2016. Feasibility of using convalescent plasma immunotherapy for MERS-CoV infection, Saudi Arabia. Emerg. Infect. Dis. 22, 1554-1561. 
Backer, J. A., Klinkenberg, D. and Wallinga, J. 2020. Incubation period of 2019 novel coronavirus (2019$\mathrm{nCoV}$ ) infections among travellers from Wuhan, China, 20-28 January, 2020. Euro. Surveill. 25, DOI: 10.2807/1560-7917.ES.2020.25.5.2000062.

Batisse, D., Benech, N., Botelho-Nerves, E., Bouiller, K., Collarino, R., Conard, A.... and Wyplosz, B. 2020. Clinical recurrences of COVID-19 symptoms after recovery: viral relapse, reinfection or inflammatory rebound? J. Infect. Published online: June 30, 2020. DOI: https://doi.org/10.1016/j.jinf.2020.06.073.

Beigel., J. H., Tomashek, K. M., Dodd, L. E., Mehta, A. K., Zingman, B. S., Kalil, A. C.... and Lane, C. 2020. Remdesivir for the Treatment of Covid-19Preliminary Report. N. Engl. J. Med. Published online: May 22, 2020. DOI: 10.1056/NEJMoa2007764.

Caly, L., Druce, J. D., Catton, M. G., Jans, D. A. and Wagstaff, K. M. 2020. The FDA-approved drug ivermectin inhibits the replication of SARS-CoV-2 in vitro. Antiviral Res. 178, DOI: https://doi.org/ 10.1016/j.antiviral.2020.104787.

Cao, B., Wang, Y., Wen, D., Liu, W., Wang, J., Fan, G.... and Wang, C. 2020. A trial of lopinavir-ritonavir in adults hospitalized with severe COVID-19. N. Engl. J. Med. 382, 1787-1799.

Ceraolo, C. and Giorgi, F. M. 2020. Genomic variance of the 2019-nCoV coronavirus. J. Med. Virol. 92, 522528.

Chen, T., Wu, D., Chen, H., Yan, W., Yang, D., Chen, G. and Ning Q. 2020. Clinical characteristics of 113 deceased patients with coronavirus disease 2019: retrospective study. BMJ. 368, DOI: $10.1136 / \mathrm{bmj}$. m1091.

Diamond, M. S. and Pierson, T. C. 2020. The challenges of vaccine development against a new virus during a pandemic. Cell Host Microbe. 27, 699-703.

EPR. 2020. MHRA approves Pfizer and BioNTech COVID-19 vaccine. Accessed December 22, 2020. Available from: https://www.europeanpharmaceutical review.com/news/135259/mhra-approves-pfizer-andbiontech-covid-19-vaccine/.

Favalli, E., Biggioggero, M., Maioli, G. and Caporali, R. 2020. Baricitinib for COVID-19: a suitable treatment? Lancet Infect. Dis. Published online: April 3, 2020. DOI: https://doi.org/10.1016/S1473-3099(20)30262-0.

Folegatti, P. M., Ewer, K. J., Aley, P. K., Angus, B., Becker, S., Belij-Rammerstorfer, S.... and Pollard A. J. 2020. Safety and immunogenicity of the ChAdOx1 nCoV-19 vaccine against SARS-CoV-2: a preliminary report of a phase 1/2, single-blind, randomised controlled trial. Lancet. Published Online: July 20, 2020; DOI:https://doi.org/10.1016/S0140-6736(20)31604-4.
Gautret, P., Lagier, J., Parola, P., Hoang, V. T., Meddeb, L., Mailhe, M... and Raoult, D. 2020. Hydroxychloroquine and azithromycin as a treatment of COVID-19: results of an open-label nonrandomized clinical trial. Int. J. Antimicrob. Agents. DOI: 10.1016/j.ijantimicag.2020.105949.

Guan, W., Ni, Z., Hu, Y., Liang, W., Ou, C., He, J. and Zhong, N. 2020. Clinical characteristics of coronavirus disease 2019 in China. N. Engl. J. Med. 382, 1708-1720.

Guaraldi, G., Meschiari, M., Cozzi-Lepri, A., Milic, J., Tonelli, R., Menozzi, M.... and Mussini, C. 2020. Tocilizumab in patients with severe COVID-19: a retrospective cohort study. Lancet Rheumatol. 2, e474-484.

Guzman, J. 2020. Can you get coronavirus twice? The Hill. Available from: https://thehill.com/changingamerica/well-being/prevention-cures/487436-can-youget-coronavirus-twice.

Hoffmann, M., Kleine-weber, H., Schroeder, S., Kruger, N., Herrler, T., Erichsen, S. and Pöhlmann, S. 2020. SARS-CoV-2 cell entry depends on ace 2 and tmprss 2 and is blocked by a clinically proven protease inhibitor. Cell 181, 271-228.

Hossain, M. J., Kuddus, M. R. and Rahman, S. M. A. 2020. Knowledge, attitudes, and behavioral responses toward COVID-19 during early phase in Bangladesh: A questionnaire-based study. Asia Pac. J. Public Health. Published Online: November 26, 2020. DOI: 10.1177/1010539520977328.

Hossain, M. J. 2020a. Impact of COVID-19 pandemic among health care providers in Bangladesh: A systematic review. Bangladesh J. Infect. Dis. 7 (suppl2), S8-S15.

Hossain, M. J. and Rahman, S. M. A. 2020. Repurposing therapeutic agents against SARS-CoV-2 infection: most promising and neoteric progress. Expert Rev. Anti-Infect. Ther. Published Online: December 23, 2020. DOI: https://doi.org/10.1080/14787210.2021. 1864327.

Hossain, M. J. 2020b. Is Bangladesh moving toward herd immunity? Current COVID-19 perspective. Bangladesh J. Infect. Dis. 7 (suppl-2), S63-S66.

Huang, C., Wang, Y., Li, X., Ren, L., Zhao, J., Hu, Y. and Cao, B. 2020. Clinical features of patients infected with 2019 novel coronavirus in Wuhan, China. Lancet 395, 497-506.

Hui, D. S. C. and Wong, G. W. K. 2004. Advancements in the battle against severe acute respiratory syndrome Advancements in the battle against severe acute respiratory. Expert Opin. Pharmacother. 5, 16871693. 
Hung, I. F., Lung, K. C., Tso, E. Y., Liu, R., Chung, T. W., Chu, M. Y.... and Yuen, K. Y. 2020. Triple combination of interferon beta-1b, lopinavir-ritonavir, and ribavirin in the treatment of patients admitted to hospital with COVID-19: an open-label, randomised, phase 2 trial. Lancet. 395, 1695-1704.

Jiang, S. and Shi, Z. L. 2020. The first disease X is caused by a highly transmissible acute respiratory syndrome coronavirus. Virol. Sin. 35, 263-265.

Jin, Y., Yang, H., Ji, W., Wu, W., Chen, S., Zhang, W. and Duan, G. 2020. Virology, epidemiology, pathogenesis, and control of COVID-19. Viruses, 12, DOI: $10.3390 / \mathrm{v} 12040372$.

Kalil, A. C., Patterson, T. F., Mehta, A. K., Tomashek, K. M., Wolfe, C. R., Ghazaryan, V.... and Beigel J. H. 2020. Baricitinib plus remdesivir for hospitalized adults with covid-19. N. Engl. J. Med. Published Online: December 11, 2020. DOI: 10.1056/NEJMoa2031994.

Kaplan, S. S. and Hicks, C. B. 2005. Lopinavir/ritonavir in the treatment of human immunodeficiency virus infection. Expert Opin. Pharmacother. 450, 15731585.

Kuhn, J. H., Li, W., Choe, H. and Farzan, M. 2004. Angiotensin-converting enzyme 2: A functional receptor for SARS coronavirus. Cell. Mol. Life Sci. 61, 2738-2743.

Lake, M. A. 2020. What we know so far: COVID-19 current clinical knowledge and research. Clin. Med. 20, 124-127.

Latham, J. 2020. The Case Is Building That COVID-19 Had a Lab Origin. Independent Science News. Published online: June 2, 2020. Available from: https://www.independentsciencenews.org/health/thecase-is-building-that-covid-19-had-a-lab-origin/.

Li, G. and Clercq, E. D. 2020a. Therapeutic options for the 2019 novel coronavirus (2019-nCoV). Nat. Rev. Drug. Discov. 19, 149-150.

Li, Q., Guan, X., Wu, P., Wang, X., Zhou, L., Tong, Y.... and Feng, Z. 2020b. Early transmission dynamics in Wuhan, China, of novel coronavirus-infected pneumonia. N. Engl. J. Med. 382, 1199-1207.

Li, Y., Zhang, Z., Yang, L., Lian, X., Xie, Y., Li, S.,...Lu, J. 2020c. The MERS-CoV receptor DPP4 as a candidate binding target of the SARS-CoV-2 spike. iScience. 23, DOI: https://doi.org/10.1016/j.isci. 2020.101160.

Liu, Y., Gayle, A. A., Wilder-Smith, A., Rocklöv, J. 2020. The reproductive number of COVID-19 is higher compared to SARS coronavirus. J. Travel. Med. 27, DOI: https://doi.org/10.1093/jtm/taaa021.
Lu, R., Zhao, X., Li, J., Niu, P., Yang, B., Wu, H.,...Tan, W. 2020a. Genomic characterisation and epidemiology of 2019 novel coronavirus: implications for virus origins and receptor binding. Lancet 395, 565-574.

Lu, X., Zhang, L., Du, H., Zhang, J., Li, Y. Y., Qu, J.... and Wong, W. K. 2020b. SARS-CoV-2 infection in children. N. Eng. J. Med. 382, 23-25.

Mamun, S. 2020. Coronavirus: Bangladesh declares public holiday from March 26 to April 4. Dhaka Tribune. Published online March 23, 2020. Available from: https://www.dhakatribune.com/ bangladesh/2020/03/23/govt-offices-to-remain-closedtill-april-4.

Mason, R. J. 2020. Pathogenesis of COVID-19 from a cell biology perspective. Eur. Respir. J. 55, DOI: 10.1183/ 13993003.00607-2020.

Mehta, P., McAuley, D. F., Brown, M., Sanchez, E., Tattersall, R. S. and Manson, J. J. 2020. COVID-19: consider cytokine storm syndromes and immunosuppression. Lancet 395, 1033-1034.

Morawska, L. and Milton, D. K. 2020. It is time to address airborne transmission of COVID-19. Clin. Infect. Dis. DOI: https://doi.org/10.1093/cid/ciaa939.

Pandey, A., Nikam, A. N., Shreya, A. B., Mutalik, S. P., Gopalan, D., Kulkarni, S. and Prassl, R. 2020. Potential therapeutic targets for combating SARSCoV-2: drug repurposing, clinical trials and recent advancements. Life Sci. 256, DOI: https://doi.org/10.1016/j.lfs.2020.117883.

Podzamczer, D., King, M. S., Klein, C. E., Flexner, C., Havlir, D. V., Letendre, S. L. and Bernstein, B. 2015. High-dose lopinavir/ritonavir in highly treatmentexperienced HIV-1 patients: efficacy, safety, and predictors of response. HIV Clin. Trials 8, 193-204.

Polack, F.P., Thomas, S.J., Kitchin, N., Absalon, J., Gurtman, A., Lockhart, S.... and Gruber, W.C. 2020. Safety and efficacy of the BNT162b2 mRNA covid19 vaccine. N. Engl. J. Med. Published Online December 10, 2020. DOI: 10.1056/NEJMoa2034577.

Qiu, H., Wu, J., Hong, L., Luo, Y., Song, Q. and Chen, D. 2020. Clinical and epidemiological features of 36 children with coronavirus disease 2019 (COVID-19) in Zhejiang, China: an observational cohort study. Lancet Infect. Dis. 20, 689-696.

Rajendran, K., Krishnasamy, N., Rangarajan, J., Rathinam, J., Natarajan, M. and Ramchandran, A. 2020. Convalescent plasma transfusion for the treatment of COVID-19: Systematic review. J. Med. Virol. doi: 10.1002/jmv.25961. 
Rashid, H., Khandaker, G. and Booy, R. 2012. Vaccination and herd immunity: what more do we know? Curr. Opin. Infect. Dis. 25, 243-249.

RECOVERY Collaborative Group, Horby, P., Lim, W. S., Emberson, J. R., Mafham, M., Bell, J. L., Linsell, L.... and Landray, M. J. 2020. Dexamethasone in hospitalized patients with covid-19-preliminary report. N. Engl. J. Med. Published Online: July 17, 2020. DOI: 10.1056/NEJMoa2021436.

Richardson, P., Griffin, I., Tucker, C., Smith, D., Oechsle, O., Phelan, A. and Stebbing, J. 2020. Baricitinib as potential treatment for 2019-nCoV acute respiratory disease. Lancet 395, DOI: https://doi.org/10.1016/ S1473-3099(20)30262-0.

Rossignol, J. 2014. Nitazoxanide: A first-in-class broadspectrum antiviral agent. Antiviral Res.110, DOI: https://doi.org/10.1016/j.antiviral.2014.07.014.

Rossignol, J. 2020. Nitazoxanide, a new drug candidate for the treatment of Middle East respiratory syndrome coronavirus. J. Infect. Public Health. 9, 227-230.

Salata, C., Calistri, A., Parolin, C. and Baritussio, A. 2017. Antiviral activity of cationic amphiphilic drugs. Expert Rev. Anti Infect. Ther.15, 483-492.

Sheahan, T. P., Sims, A. C., Graham, R. L., Menachery, V. D., Gralinski, L. E., Case, J. B.... and Baric, R. S. 2017. Broad-spectrum antiviral GS-5734 inhibits both epidemic and zoonotic coronaviruses. Sci. Transl. Med. 9, DOI: 10.1126/scitranslmed.aal3653.

Shereen, M. A., Khan, S., Kazmi, A., Bashir, N. and Siddique, R. 2020. COVID-19 infection: Origin, transmission, and characteristics of human coronaviruses. J. Adv. Res. 24, 91-98.

Shiraki, K. and Daikoku, T. 2020. Pharmacology \&therapeutics favipiravir, an anti-influenza drug against life-threatening RNA virus infections. Pharmacol. Ther. 209, DOI: 10.1016/j.pharmthera. 2020.107512.

Simonovich, V. A., Burgos Pratx, L. D., Scibona, P., Beruto, M. V., Vallone, M. G., Vázquez, C.... and Belloso, W.H. A randomized trial of convalescent plasma in covid-19 severe pneumonia. N. Engl. J. Med. Published Online November 24, 2020. DOI: 10.1056/NEJMoa2031304.

Stockman, L. J., Bellamy, R. and Garner, P. 2006. SARS: Systematic review of treatment effects. PLoS Med. 3, DOI:10.1371/journal.pmed.0030343.

Stone, J. H., Frigault, M. J., Serling-Boyd, N. J., Fernandes, A. D., Harvey, L., Foulkes, A. S.... and Mansour, M. K. Efficacy of tocilizumab in patients hospitalized with covid-19. N. Engl. J. Med. 383, 2333-2344.

Syal, K. 2020. COVID-19: Herd immunity and convalescent plasma transfer therapy. J. Med. Virol. DOI:10.1002/jmv.25870.
Tang, B., Wang, X., Li, Q., Bragazzi, N. L., Tang, S., Xiao, Y. and $\mathrm{Wu}$, J. 2020a. Estimation of the transmission risk of the 2019-nCoV and its implication for public health interventions. J. Clin. Med. 9, DOI:10.3390/ jem9020462.

Tang, B., Bragazzi, N. L., Li, Q., Tang, S., Xiao, Y. and $\mathrm{Wu}$, J. 2020b. An updated estimation of the risk of transmission of the novel coronavirus (2019-nCoV). Infect. Dis. Model. 5, 248-255.

Tang, W., Cao, Z., Han, M., Wang, Z., Chen, J., Sun, W.... and Xie, Q. 2020c. Hydroxychloroquine in patients with mainly mild to moderate coronavirus disease 2019: open label, randomised controlled trial. BMJ. 369, DOI: $10.1136 / \mathrm{bmj} . \mathrm{m} 1849$.

Trial Site News. 2020. Russia Ministry of Health Approves Avifavir (Favipiravir) for COVID-19 Patients-Cuts Duration of Illness by over $50 \%$. Published online: June 1, 2020. Available from: https://www. trialsitenews.com/russia-ministry-of-health-approvesavifavir-favipiravir-for-covid-19-patients-cutsduration-of-illness-by-over-50/.

USFDA. 2020. Coronavirus (COVID-19) Update: FDA Issues Emergency Use Authorization for Potential COVID-19 Treatment. Published online: May 1, 2020. Available from: https://www.fda.gov/news-events/ press-announcements/coronavirus-covid-19-updatefda-issues-emergency-use-authorization-potentialcovid-19-treatment.

Vincent, M. J., Bergeron, E., Benjannet, S., Erickson, B. R., Rollin, P. E., Ksiazek, T. G. and Nichol, S. T. 2005. Chloroquine is a potent inhibitor of SARS coronavirus infection and spread. Virol. J. 2, DOI: 10.1186/1743-422X-2-69.

Wan, Y., Shang, J., Graham, R., Baric, R. S. and Li, F. 2020. Receptor recognition by the novel coronavirus from wuhan: an analysis based on decade-long structural studies of SARS coronavirus. J. Virol. 94, DOI: 10.1128/JVI.00127-20.

Wang, Q., Wong, G., Lu, G. and Yan, J. 2016. MERS-CoV spike protein: targets for vaccines and therapeutics. Antiviral Res. 133, 165-177.

Wang, X., Fang, J., Zhu, Y., Chen, L., Ding, F., Zhou, R. and Zhao, Q. 2020a. Clinical characteristics of noncritically ill patients with novel coronavirus infection (COVID-19) in a Fangcang Hospital. Clin. Microbiol. Infect. DOI: 10.1016/j.cmi.2020.03.032.

Wang, D., Hu, B., Hu, C., Zhu, F., Liu, X., Zhang, J.... and Peng, Z. 2020b. Clinical characteristics of 138 hospitalized patients with 2019 novel coronavirusinfected pneumonia in Wuhan, China. J. Am. Med. Assoc. 323, 1061-1069.

WHO. 2020. Draft landscape of COVID-19 candidate vaccines. July 14, 2020. Available from: https://www.who.int/publications/m/item/draftlandscape-of-covid-19-candidate-vaccines. 
WHO Solidarity Trial Consortium, Pan. H., Peto, R., Henao-Restrepo, A. M., Preziosi, M. P., Sathiyamoorthy, V., Abdool Karim, Q.....and Swaminathan, S. 2020. Repurposed antiviral drugs for covid-19 - interim WHO solidarity trial results. $N$. Engl. J. Med. Published Online: December 2, 2020. DOI: 10.1056/NEJMoa2023184.

Wrapp, D., Wang, N., Corbett, K. S., Goldsmith, J. A., Hsieh, C., Abiona, O. and McLellan, J. S. 2020. CryoEM structure of the 2019-nCoV spike in the prefusion conformation. Sci. 367, 1260-1263.

Wu, Z. and McGoogan, J. M. 2020. Characteristics of and important lessons from the coronavirus disease 2019 (COVID-19) outbreak in China: summary of a report of 72314 cases from the chinese center for disease control and prevention. J. Am. Med. Assoc. 323, 12391242.

Xiao, F., Tang, M., Zheng, X., Li, C., He, J. and Hong, Z. 2020. Evidence for gastrointestinal infection of SARS-CoV-2. Gastroenterol. 158, 1831-1833.

Xiong, Z., Xin, C., Yan, X., Cai, Y., Zhou, K., Xie, C. and Zhang, T. 2020. Clinical characteristics and outcomes of 421 patients with COVID-19 treated in a mobile cabin hospital. Chest. DOI: https://doi.org /10.1016/j.chest.2020.05.515.

Xu, X., Han, M., Li, T., Sun, W., Wang, D., Fu, B.... and Wei, H. 2020. Effective treatment of severe COVID19 patients with tocilizumab. Proc. Natl. Acad. Sci., USA 117, 10970-10975.
Yu, N., Li, W., Kang, Q., Xiong, Z., Wang, S., Lin, X.... and Wu, J. 2020. Clinical features and obstetric and neonatal outcomes of pregnant patients with COVID-19 in Wuhan, China: a retrospective, singlecentre, descriptive study. Lancet Infect. Dis. 20, 559564.

Yuki, K., Fujiogi, M. and Koutsogiannaki, S. 2020. COVID-19 pathophysiology: a review. Clin. Immunol. 215, DOI: $10.1016 /$ j.clim.2020.108427.

Zhang, Y. and Holmes, E. C. 2020. A genomic perspective on the origin and emergence of SARS-CoV-2. Cell 181, 223-227.

Zhao, S., Lin, Q, Ran, J., Musa, S. S., Yang, G., Wang, W.... and Wang, M. H. 2020. Preliminary estimation of the basic reproduction number of novel coronavirus (2019-nCoV) in China, from 2019 to 2020: A datadriven analysis in the early phase of the outbreak. Int. J. Infect. Dis. 92, 214-216.

Zhou, F., Yu, T., Du, R., Fan, G., Liu, Y., Liu, Z... and Cao, B. 2020. Clinical course and risk factors for mortality of adult inpatients with COVID-19 in Wuhan, China: a retrospective cohort study. Lancet 395, 1054-1062.

Zou, X., Chen, K., Zou, J., Han, P., Hao, J. and Han, Z. 2020. Single-cell RNA-seq data analysis on the receptor ACE2 expression reveals the potential risk of different human organs vulnerable to 2019-nCoV infection. Front. Med. 14, 185-192. 